\title{
Leven voor de dood. Aanzetten tot een christelijke thanatologie
}

\author{
T.T.J. Pleizier
}

\begin{abstract}
Popular literature shows the need for a contemporary art of dying. This article argues for a Christian thanatology that engages modern phenomena such as near-death-experiences, end-of-life legislation and an imagination that cannot envisions life beyond death. Reformed sources provide three elements for a Christian thanatology: (a) death as the boundary of human existence; (b) a spiritual attitude toward death; and (c) death and as an eccentric existence. A Christian thanatology moves beyond a systematictheological exploration of the 'last things' to offer a 'practical eschatology' able to relate Christian imagination with cultural expressions.
\end{abstract}

\section{Inleiding}

Onlangs verscheen bij uitgeverij Ten Have na vijftien jaar een nieuwe editie van Pim van Lommels Eindeloos bewustzijn over bijna-doodervaringen van Nederlanders die een hartstilstand in het ziekenhuis hebben overleefd. Van Lommels boek was een doorslaand succes. De grens van leven en dood blijft ons mensen intrigeren. De populariteit van Van Lommels boek wekt de suggestie dat het helemaal niet zo makkelijk te verteren is dat na de dood alles zomaar ophoudt. In het boek vertellen mensen die een bijna-doodervaring hebben meegemaakt hoe deze ervaring hen diepgaand heeft veranderd. Het heeft grote impact op ons leven in het heden als de werkelijkheid van (onze eigen) dood en het voortbestaan na de dood zich aan ons opdringen. Daar hebben ook religies weet van. Religie kan worden gezien als een psychologisch mechanisme (coping) om de angst voor de dood en de onzekerheid van het onbekende land achter de dood hanteerbaar te maken. Religie is echter meer. De dood en het Heilige hebben gemeen dat onze menselijke respons vergelijkbaar is. De godsdienstfilosoof Merold Westphal wijst erop dat Rudolf Otto's typering van het Heilige als dat wat ons fascineert en dat wij tegelijk vrezen, ook geldt voor de realiteit van de dood. ${ }^{1}$ Van Lommels boek toont aan

1 Merold Westphal, God, Guilt, and Death: An Existential Phenomenology of Religion, Bloomington 1984, 37-45. 
dat ook in de postchristelijke, of moeten we inmiddels zeggen: postseculiere, West-Europese cultuur de fascinatie voor de dood niet is verdwenen. Dat vraagt ook om nadere reflectie op de omgang met de dood en de schaduwen die de dood vooruitwerpt in het leven.

Omdat ik deze bijdrage schrijf als praktisch-theoloog, zal ik minder ingaan op de dogmatische vragen hoe het leven na de dood vanuit het christelijk geloof gedacht kan worden en hoe dat in verband staat met hedendaagse verbeeldingen. Mijn aandacht gaat meer uit naar de voorbereiding op de dood. Anders gezegd, wat betekent de christelijke overtuiging dat er na de dood een vernieuwd leven wacht, voor hoe we de dood tegemoetleven? N.T. Wright is bekend geworden met zijn uitdrukking dat christenen geloven in de opstanding als 'het leven ná het leven na de dood' ('life after life after death'). ${ }^{2}$ In dit artikel gaat het meer om 'de dood vóór het leven na de dood'. In de dood vóór het leven na de dood gaat het om praktijken en overtuigingen tijdens het leven.

Wat is vanuit het christelijk geloof van belang in verband met de realiteit van de (eigen) dood? Vanuit Van Lommel ligt het voor de hand om vanuit het voortbestaan van menselijk bewustzijn opnieuw aandacht te vragen voor de ziel op de grens van leven en dood. Zo bespreken Van den Brink en Van der Kooi de dood in relatie tot de vraag naar de ziel: 'De radicale breuk die de dood veroorzaakt, dient christelijk gesproken ernstig te worden genomen.'3 Toch speelt de grens van de dood een relatief kleine rol in hedendaagse dogmatische $e^{4}$ en pastorale literatuur. ${ }^{5}$ Daarom is het goed om toch iets nader stil te staan bij het theologisch nadenken over de dood in de laatmoderne wes-

2 N.T. Wright, Surprised by Hope. Rethinking Heaven, the Resurrection, and the Mission of the Church, New York 2007, 148.

3 G. van den Brink, C. van der Kooi, Christelijke dogmatiek: een inleiding, Zoetermeer 2012, 251. Belangrijk is het onderzoek waar zeer recent Martine Oldhoff op promoveerde: Soul Searching with Paul: A Theological Investigation of Cultural, Traditional, and Philosophical Concepts of the Soul (PThU diss. 2021).

4 De dood komt ter sprake in de locus van de eschatologie, waarbij de opstanding van de doden besproken wordt als één van de vier 'laatste dingen' (a.w., 665).

5 Het begeleiden van stervenden is in de oude pastorale literatuur letterlijk het sluitpunt van de bezinning. Eduard Thurneyssen en Thomas Oden, om twee voorbeelden te noemen, bespreken het begeleiden van stervenden in het laatste hoofdstuk van hun pastorale theologie. Zie Eduard Thurneysen, Seelsorge im Vollzug, Zürich 1968; Thomas C. Oden, Pastoral theology: essentials of ministry, San Francisco 1983. In meer recente pastorale leerboeken is het onderwerp als zelfstandig thema nagenoeg verdwenen. Vgl. Ruard Ganzevoort, Jan Visser, Zorg voor het verhaal. Achtergrond, methode en inhoud van pastorale begeleiding, Kampen 2007; Christoph Morgenthaler, Seelsorge (Lehrbuch praktische Theologie: Bd. 3), Gütersloh 2009. 
terse cultuur. Ik werk dat vervolgens kort uit aan de hand van een drietal theologische thema's.

\section{Afbakening: theologisch nadenken over de dood}

Leven en dood bestrijken ongeveer het hele existentiële spectrum van het mens-zijn. Naast ons eigen mens-zijn, gaat het ook over leven en dood van andere mensen, mensen die ons nabij zijn, maar ook de vele - vaak - naamloze levenden en doden van wie verhalen tot ons komen. En ook onze eigen dood is niet pas in beeld aan het eind van het leven; gedurende het leven doen wij veel ervaringen op die onze eigen sterfelijkheid dichtbij brengen. Ervaringen van sterfelijkheid bevinden zich tussen de extremen van doodsverachting en doodsverlangen, van het ontkennen van de dood tot het omhelzen ervan. Kortom: leven en dood raken ons allen, onszelf en anderen, en ze raken ons tot in het diepst van ons menselijk bestaan.

Het godsdienstig spreken en denken over leven en dood vindt niet plaats in een vacuüm. In de laatmoderne cultuur mag het spreken over de dood een taboe zijn waar populaire boeken als die van Katy Butler, De kunst van het sterven (2020), terecht de vinger bij leggen. Toch staat de dood regelmatig op de politieke en maatschappelijke agenda: het ideologische verlangen naar een voltooid-levenwet, nieuwe wetgeving op het terrein van de lijkbezorging, botsende (grond)rechten over de ruimte voor het afbreken van zwangerschappen en verruiming van euthanasiewetgeving. Deze onderwerpen hebben een sterk contextueel-culturele component: ze lijken samen te hangen met de laatmoderne, westerse cultuur, waarin de rol van religie sterk is verminderd, mensen individueel betekenis moeten geven aan hun leven, en daarbij ook hun eigen morele ruimte innemen als het gaat om hun eigen dood. Deze contextuele aspecten zijn daarbij altijd ethisch geladen: wat mag onder welke omstandigheden wel of niet, en voor wie en wanneer?

$\mathrm{Nu}$ gaat het in deze bijdrage niet om een cultuurtheologische of een ethische reflectie. Cultuurtheologische reflecties hebben als centrale vraag hoe fenomenen in de ons omringende cultuur geduid kunnen worden vanuit de theologie. Of, meer productiever, hoe culturele uitingen, houdingen of trends bijdragen aan verdieping en verbreding van de theologie. In het werk van Erik Borgman vinden we deze benadering terug. ${ }^{6}$ In Leven van wat komt komt Borgman een aantal keren terug op de samenleving als 'lichaam van gebroken beenderen'. Niet zozeer de dood als ingreep in het individuele leven, maar de

6 Erik Borgman, Wortelen in vaste grond: een cultuurtheologisch essay, Zoetermeer 2009; Erik Borgman, Leven van wat komt: een katholiek uitzicht op de samenleving, Utrecht 2017. 
fundamentele kwetsbaarheid van het bestaan vraagt om een theologisch antwoord. Borgman voert een pleidooi voor een contemplatief standpunt, waarin het gebroken lichaam, met de woorden van Thomas Merton, kan worden gezien als 'het lichaam waarmee Christus bezig is te verrijzen'. ${ }^{7}$ De cultuurtheologie duidt en verrijkt het maatschappelijk denken en het hedendaagse levensgevoel met inzichten vanuit de theologie.

De ethiek stelt de vraag naar leven en dood vanuit het gezichtspunt van de moraal: is het goed of minder goed om orgaandonatie te verplichten? Is het moreel acceptabel om hulp bij zelfdoding te bieden of moeten mensen wettelijk gezien de mogelijkheid krijgen om een einde aan hun leven te maken als zij dat als voltooid beschouwen? Over de ervaringen van nabestaanden in situaties van euthanasie verscheen recent een boeiende bundel, Leven met euthanasie. ${ }^{8}$ De bundel illustreert hoe belangrijk het is om bij ethisch geladen thema's goed te luisteren naar hoe situaties voor mensen uitwerken. Daarmee wordt de normatieve vraag niet geparkeerd, maar wordt wel een ander belang aangewezen: hoe bereiden we ons voor op de dood en hoe gaan we om met de (zelfgekozen) dood?

Hier sla ik een brug naar een meer praktisch-theologische benadering. Wat staat er theologisch op het spel bij de grote thema's op het terrein van leven en dood en wat betekent dat voor de praktijken van verkondiging en zielzorg? Het gaat hier om christelijk denken over de dood en de omgang met de dood. Of, aangeduid met de specifieke discipline die zich bezighoudt met sterven en dood: het gaat om enkele aanzetten tot een christelijke thanatologie. ${ }^{9}$

Zoals hierboven reeds aangegeven, thanatologie lijkt een marginaal thema te zijn in hedendaagse christelijke dogmatische en pastoraal-theologische literatuur. Allen Verhey merkt op dat het ironisch is dat

the community that has a story of death at the center of its Scripture and at the center of its practices of baptism and Eucharist should fall so often silent about death and about the practices of dying well and faithfully and of caring well and faithfully for the dying. ${ }^{10}$

7 Borgman, Leven van wat komt, 57.

8 Theo Boer, Stef Groenewoud, Wouter de Jonge, Leven met euthanasie: geliefden vertellen over hun ervaringen, Utrecht 2021.

9 Thanatologie is een interdisciplinair veld van wetenschappelijke bezinning. Vgl. David K. Meagher, David E. Balk (red.), Handbook of Thanatology: The Essential Body of Knowledge for the Study of Death, Dying, and Bereavement, New York, NY 22013.

10 Allen Verhey, The Christian Art of Dying: Learning from Jesus, Grand Rapids 2011, 73-74. 
In dit artikel geef ik slechts een paar aanzetten. Het gaat om drie samenhangende thematieken die om nadere uitwerking vragen en die, zoals blijkt, elk een eigen belang hebben in het denken over de dood in de laatmoderne westerse cultuur. Allereerst sta ik stil bij de dood als grens in het bestaan. Dat roept vervolgens de vraag op naar de geestelijke houding ten opzichte van de dood. De derde aanzet voor een christelijke thanatologie betreft een fundamentele beslissing in de theologische antropologie: ons menselijk bestaan is principieel te typeren als 'excentrisch'.

\section{De dood als grens in het bestaan}

In haar boek Je kunt het maar één keer doen biedt Barbara van Beukering, precies zoals de ondertitel het aangeeft, 'een persoonlijke zoektocht naar sterven, het grootste taboe in ons leven'. Van Beukering schrijft over het sterven van haar ouders en de confrontatie met haar eigen sterfelijkheid. In haar zoektocht spreekt ze met een aantal bekende Nederlanders die een geliefde verloren. Niet zozeer over wat het verlies met hen deed als achterblijvers, maar hoe de voorbereiding op de dood plaatsvond. Sterven is vooral weggaan. Zoals René Gude, de voormalig denker des vaderlands, het uitdrukte: 'Ik vind het zo jammer dat ik weg moet.'11

Beukerings boek laat zien hoe de dood een massieve grens aan ons menselijk leven markeert, een grens die we minder goed onder ogen kunnen komen dan vorige generaties dat konden. Wat Beukering beschrijft, treffen we ook aan in het boek van Katy Butler, De kunst van het sterven. Butler en Beukering laten zien hoe het sterven buiten het gewone leven terecht is gekomen. Dat heeft twee redenen. Ten eerste, leven we langer dan ooit; de dood verschuift mee met de levensverwachting. Terwijl vorige generaties voortdurend te maken hadden met het sterven van kinderen, van mensen in de kracht van hun leven én van ouderen. Als de dood erbij hoort, leer je ermee om te gaan. Ten tweede is de dood gemedicaliseerd: de meeste mensen sterven buitenshuis, in een ziekenhuis of een instelling. De dood is daarmee over de rand van ons dagelijkse leven geduwd.

Wanneer we theologisch over de dood nadenken, kunnen we de grens van de dood op een aantal manieren benaderen.

Allereerst gaat het om de vraag in hoeverre we de dood als een natuurlijke of een godsdienstige grens zien en daarover spreken. Hoort de dood bij het leven, omdat we nu eenmaal beperkte schepselen zijn en eeuwigheid een kwa-

11 Barbara van Beukering, Je kunt het maar één keer doen: een persoonlijke zoektocht naar sterven, het grootste taboe in ons leven, Amsterdam 2020, 142. 
liteit van God is en niet van zijn schepselen? Of is de dood toch vooral een straf op de zonde? Zoals over verkiezing en christologie valt er ook over de dood infra- en supralapsarisch te denken. Het voert hier te ver om bijbelstheologische spanningen verder uit te werken, ${ }^{12}$ of om nader in te gaan op de verwerking van evolutionistisch denken in de christelijke theologie. In elk geval zorgt het godsdienstige perspectief ervoor dat we over de dood niet te gemakkelijk spreken als over iets dat nu eenmaal bij het leven hoort. Dat de dood ook een oordeel is, geeft vanuit het christelijk gezichtspunt ruimte om recht te doen aan de weerstand ertegen. Het innerlijk verzet tegen de gedachte dat de dood een oordeel over de zonde is, maakt voelbaar dat de dingen niet zijn zoals ze moeten zijn. Tegelijk is het van belang om te aanvaarden dat een mens nu eenmaal sterfelijk en eindig is. Dit dubbele motief van oordeel en eindigheid is niet eenvoudig theologisch, laat staan existentieel, op te lossen.

Ten tweede moet gezegd worden dat de dood een mysterie is en blijft. In het christelijk geloof lijken er twee overtuigingen te zijn die zich wat tegen het mysterieuze karakter van de dood verzetten. Ten eerste, de lange geschiedenis die teruggaat tot de bijbelse bronnen waarin vaak met veel verbeelding gesproken wordt over de 'twee wegen' van hemel en hel na de dood. Daar ligt een zekere duidelijkheid in. Ten tweede, het geloof in de opstanding van Christus uit de dood. Het christelijk geloof lijkt daarmee een antwoord te bieden op het geheim van de dood: wij weten van een leven ná de dood.

$\mathrm{Nu}$ is de opstanding van Christus in de bijbelse getuigenissen echter minstens zo mysterieus als de dood zelf en roept meer de vraag naar continuïteit en discontinuiteit op, dan dat deze vraag erdoor wordt beantwoord. Paulus' typering van het opstandingslichaam als een 'geestelijk lichaam' blijft even raadselachtig als het getuigenis dat de Opgestane niet zomaar herkend werd door zijn leerlingen. En ook de christelijke overtuiging dat er na dit leven een oordeel wacht dat twee mogelijke uitkomsten kent, een voortbestaan binnen of buiten het Rijk van God, heeft in de (kunst)geschiedenis tot een veelheid aan verbeeldingen geleid, waarmee de raadselachtigheid van het bestaan na de dood alleen maar werd onderstreept. Ook in een christelijke thanatologie blijft de dood een mysterie. Wij blijven over de dood terughoudend spreken, ondanks, of misschien juist wel dankzij, de geloofsovertuigingen van oordeel en opstanding.

De dood bepaalt ons bij onze eindigheid. Daarmee is ten derde ook iets gezegd over ons bestaan in de tijd. Ieder mens moet sterven en wanneer het je

12 Zie vooral de bijdragen van Paul en Van Spanje in dit themanummer. 
tijd is, dat weet niemand. Ook niet degene die op voorhand een wilsbeschikking ten aanzien van euthanasie heeft ingevuld. Vanuit de Schrift komen dan woorden op als 'mijn tijden zijn in Uw hand' (Ps. 31) en 'de dood wenkt ieder uur' (Ps. 89, berijmd).

Tegelijk moeten we ons bewust zijn dat deze bijbelse woorden geschreven zijn in een tijd waarin de dood veel minder medisch en technisch gereguleerd kon worden zoals in onze tijd dat wel het geval is. De bijbelse teksten komen uit een tijd waarin de dood veel grilliger aanwezig was in de wereld. In de laatmoderne westerse cultuur wordt het leven als veel minder onzeker ervaren. Hoe zit het dan met de hand van God en hoe zit het met de eindigheid van ons bestaan?

Langere levens, technische middelen om levens te verlengen en toenemende mogelijkheden om ook ernstige ziekten te beheersen, hebben de onzekerheid voor een groot deel uit onze levens verbannen. Heel anders was dat in de eeuwen hiervoor, waar mensen in alle lagen van de bevolking op allerlei momenten onverwachts geconfronteerd werden met de dood. Dat heeft tot paradoxaal gevolg dat als het leven minder onzeker is, we het moeilijker vinden om met onzekerheid om te gaan. Dat wij het tijdstip van onze dood medisch en technisch beter kunnen beheersen, houdt overigens niet in dat we daarmee ook ontkennen dat ons leven niet of niet meer in de hand van God is. Juist de toenemende dominantie van techniek roept een tegenbeweging op. De opkomst van kunstmatige intelligentie, algoritmes die onze zoekopdrachten sturen en bepalen wat wij te zien krijgen op het scherm van onze smartphone, de grote rol die techniek heeft in medische trajecten: techniek geeft ons ook een gevoel van machteloosheid. Wij zijn veel minder de autonome mensen die tot in de kleinste details over het eigen leven kunnen beschikken.

Dat het christelijk geloof vasthoudt aan het leven dat in de hand van God is, laat niet alleen een waarde zien die tegen de cultuur ingaat. Het is, om met de bekende inzet van de Heidelbergse Catechismus te spreken, in een door techniek overheerste cultuur een troostend inzicht dat mijn bestaan in de handen van Christus ligt.

\section{Een geestelijke houding ten aanzien van de dood}

Daarmee kom ik bij een tweede theologisch thema voor een verdere ontwikkeling van een christelijke thanatologie. De begrensdheid van de mens roept ook een reactie op. Die respons kan gezien worden als een geestelijke houding ten aanzien van de dood. Anders gezegd, om een spiritualiteit van het sterven. In de klassieke teksten waarin het om voorbereiding op de dood - of stervenskunst (ars moriendi) - gaat, krijgt deze houding veel aandacht.

In zijn Praktijk der godzaligheid wijst Gisbertus Voetius er bijvoorbeeld op 
dat de kunst van het sterven bestaat uit een goede voorbereiding tijdens het leven en de praktijk van het sterven zelf. Als het om de goede voorbereiding gaat, dan noemt Voetius drie aspecten: de levende omgang met God; manieren om onszelf te bemoedigen bijvoorbeeld door de dood te leren zien in de samenhang met Christus' dood, en maatregelen in relatie tot de naaste. Bij dat laatste noemt hij bijvoorbeeld het nastreven van verzoening met andere mensen of het treffen van regelingen voor materiële zaken met het oog op hen die achterblijven. ${ }^{13}$ Voetius beschrijft daarin een spiritualiteit van de dood die gericht is op God, op de eigen persoon en op de naaste. De geestelijke houding die Voetius beschrijft staat niet op zichzelf, maar moeten we plaatsen tegen de achtergrond van een rijke geschiedenis van stervensliteratuur. Daarna is het langzaam stil geworden. K. Exalto wijt dit aan het opkomende vooruitgangsgeloof: 'Men raakte met deze wereld tevreden.' 14

Alsof de wal het schip moet keren, benadrukken de eerdergenoemde hedendaagse auteurs Kate Butler en Barbara van Beukering dat de kunst van het sterven in onze tijd opnieuw geleerd moet worden. Tegenover de dood weten we ons nauwelijks nog een houding te geven, zo betogen zij. In haar boek met ervaringsverhalen vertelt Van Beukering aangrijpende voorbeelden van mensen die eenzaam sterven omdat zij elk gesprek over de naderende dood uit de weg gaan. Uit Van Beukerings zoektocht naar sterven wordt duidelijk dat wij onze gevoelens moeten leren delen, dat de manier waarop wij ons voorbereiden op onze eigen dood voor de verwerking van anderen van groot belang is, en dat alleen een besef van eindigheid helpt om goed te kunnen leven.

Het 'gedenk te sterven' (memento mori) blijkt springlevend te zijn in de hedendaagse zoektocht naar het goede sterven. Els van Wijngaarden, onderzoeker aan de Universiteit van Humanistiek, beschrijft een verschuiving in de houding ten aanzien van de dood: niet langer staat het verschijnen voor God en het hiernamaals op de voorgrond. Het gaat nu vooral om het voorkomen van onnodig lijden en om een goede dood voor mijzelf en mijn naasten. ${ }^{15}$ Ligt deze verschuiving wellicht onder de huidige discussie over 'voltooid leven'? Waar tijdig gezocht wordt naar een goed levenseinde en de mens daar zelf

13 Gisbertus Voetius, De praktijk der godzaligheid. Ta Asketika sive Exercitia pietatis (1644). Tekstuitgave met inleiding, vertaling en commentaar door C.A. de Niet, deel 2, Utrecht 1996, 430-439.

14 K. Exalto, De dood ontmaskerd, Amsterdam 1975, 224.

15 Els van Wijngaarden, Memento mori revisited: nieuw zorgethisch onderzoek naar keuzes rond de dood, in: Zorgethiek.nu, 13-7-2020. 
regie in houdt. Deze verschuiving past bij een proces van secularisering waarbij de werkelijkheidsbeleving steeds immanenter is geworden. ${ }^{16}$ Toch is het opvallend dat in de klassiek-christelijke stervensliteratuur zoals we zojuist tegenkwamen bij Voetius geen tegenstelling wordt gemaakt tussen het verschijnen voor God en het zoeken naar een goed sterven, waarbij ook aandacht is voor het dragen van het lijden en het zo mogelijk verlichten daarvan. Daarmee is de angel niet uit de discussie over 'voltooid leven'. Eerder stelt 'voltooid leven' de vraag hoe we een spiritualiteit van sterven kunnen ontwikkelen, waarbij de dood geen taboe is en een mens de grens van de dood niet zonder hoop tegemoettreedt, en waarbij de naasten die achterblijven geholpen zijn.

Spiritualiteit is hier een goed woord, omdat daarmee ook de taboe van het vóór en het ná de dood aan de orde moet komen. De innerlijke houding waarmee een mens de dood tegemoetleeft. Ook in een seculiere samenleving zijn er voorstellingen van de dood. En ook sterk uitgesproken christelijke overtuigingen zullen bij alle voorstellingen die er zijn de nodige terughoudendheid moeten betrachten. Niet alleen vanuit de christelijke bronnen, maar juist ook binnen de christelijke gemeenschap en in christelijke geloofsprakijken kan geoefend worden met het loslaten van de taboe op sterven en dood. Laat de christelijke gemeente een veilige omgeving zijn om een geestelijke houding ten opzichte van de dood te ontwikkelen of een passende respons op onze eindigheid te oefenen.

\section{Sterven en een excentrisch bestaan}

De werkelijkheid van de dood markeert twee levenshoudingen. De houding dat er na de dood nog iets te verwachten valt, of de houding dat met de dood aan alles een eind komt. Twee begrippenparen lopen vaak samen op. Tegenover hiernamaals treffen we nogal eens het begrip 'hiernumaals' aan; en de immanente levenshouding waarin er geen hiernamaals is, heeft als keerzijde vaak de transcendente levenshouding: de houding dat er meer is dan het materiële. $\mathrm{Nu}$ is 'transcendent' een complex begrip. Ook in non-religieus, seculier of humanistisch discours bestaat er transcendentie: verbeeldingen van het goede die ellende overstijgen. ${ }^{17}$

Maar ook al is er ruimte voor zelftranscendentie, christelijk spreken over de dood brengt een andere oriëntatie in. Ook als ons vertrekpunt altijd déze

16 Charles Taylor, A Secular Age, Cambridge, MA/Londen 2007.

17 Carmen Schuhmann, Annelieke Damen, Representing the Good: Pastoral Care in a Secular Age, in: Pastoral Psychology (2018), 1-13, DOI: 10.1007/s11089-018-0826-0. 
wereld is. We kunnen immers niet ontsnappen uit deze wereld, zoals Emanuél Levinas stelt:

$\ldots$ it is in the world, that we come into the world, and in the world that we go out of the world. In the world, we are always already subsumed under the worldly. There is no liberation. ${ }^{18}$

Ook als er niet anders dan vanuit déze wereld gesproken kan worden over het úit de wereld gaan, dan houdt dat niet in dat met déze wereld alles wel is gezegd. We raken hier aan de eschatologie. Daarmee betreden we - eindelijk - het terrein dat handelt over 'leven na de dood'. Het citaat van Levinas is hierom van belang dat vanuit praktisch-theologisch perspectief vooral van belang is om aandacht te hebben voor de wijze waarop de mens zich in dit leven en vanuit déze wereld zich op het 'uit dit leven gaan' voorbereidt, inclusief de overtuigingen, verwachtingen en voorstellingen die daarbij horen.

Op dit punt aangekomen gaat het dus niet primair om een systematischtheologische uitwerking van wat er christelijk gesproken over het bestaan ná dit leven gezegd kan worden, maar om een meer 'praktische eschatologie'. Hier speelt de geloofsbeleving een belangrijke rol, met alle voorstellingen en religieuze gevoelens die daarin meedoen. Met andere woorden: in de spiritualiteit van het sterven en het toeleven naar de dood gaat het minder om vragen óf hemel en hel er zijn en hoe zij gedacht moeten worden, hoe we ons de wederkomst van Christus kunnen voorstellen en welke laatste dingen te verwachten zijn. In het aangezicht van de dood gaat het om de vraag hoe déze mens staat tegenover God. Welke verlangens en angsten in relatie tot God vragen om pastorale aandacht? Hoe kijkt deze mens naar het bestaan ná de dood? Kortom: hoe staat het met onze ziel bij het verlaten van deze wereld?

Een dergelijke 'praktische eschatologie' lijkt nogal antropologisch van aard te zijn. Toch is het meest beslissende de vraag hoe vanuit déze mens over God gesproken wordt, naar God gevraagd wordt en wie God is op de grens van leven en dood en achter deze grens.

Hoewel Levinas ons erbij bepaalt dat hier principieel vanuit de menselijke ervaring en daarmee vanuit déze wereld wordt gedacht, betekent dit niet een volstrekte antropologisering van het christelijk geloof. Een belangrijke bijdrage op dit punt is geleverd door David Kelsey. In zijn invloedrijke theologische 
antropologie Eccentric Existence (2009) ${ }^{19}$ ontwikkelt Kelsey een antropologie waarin de gerichtheid op de drie-ene God wordt uitgewerkt als een centrum dat búiten (eccentrisch) ons ligt. Het voert te ver Kelseys denken te verbinden aan de mens als beeld van God (imago Dei); Kelsey doet dat wel, maar zoekt via de christologie (Jezus Christus als beeld van God) een weg tussen de abstrahering (mensheid) en déze mens. ${ }^{20}$ Daar ligt wel direct de aanzet voor een 'praktische eschatologie': waar ligt het verlangen van déze mens over de dood heen, en hoe staat dat verlangen in verband met de Drie-ene?

Vanuit deze trinitarische uitwerking van de theologische antropologie dient zich een aantal thema's aan dat van belang is voor een verdere uitwerking van een christelijke thanatologie. In de klassieke stervensliteratuur, zoals we dat eerder al bij Voetius tegenkwamen, gaat het dan bijvoorbeeld om een gerust sterven in het vertrouwen op Christus, om het tegemoetzien van het gericht over ons aardse bestaan, en om het schouwen van God (visio Dei) als de ultieme 'verbeelding' van de heerlijkheid die wacht. Zodra we het leven voor de dood in relatie zien tot God en het menselijk bestaan als excentrisch verstaan, dan roept dat als vanzelf twee vervolgvragen op. Allereerst: hoe staat het met de relatie tussen God en (mede)mens? Dan gaat het om praktijken van verzoening en heling: voor de dood in het reine komen met het geleefde leven. En daarom ook een tweede vraag: in welk licht staat het geleefde leven? Het geleefde leven verdwijnt niet zomaar, maar blijft bestaan in de vorm van het gericht. Zowel verzoening als oordeel moet excentrisch worden uitgewerkt: het gericht ligt in de handen van God en verzoening komt tot ons als een geschenk.

Dit alles vraagt om een thanatologie die verder gaat dan zingeving aan het einde van een mensenleven. Het christelijk geloof stelt dan de ultieme vraag naar de verhouding tot God. Dat veronderstelt dat ons bestaan principieel open is; het leven voltrekt zich niet onder een gesloten hemel, het is niet een meer of minder geslaagd individueel project. Al blijft de dood een groot mysterie, dat de band met God niet tenietgedaan wordt door de dood, breekt ons bestaan open. Het centrum ligt niet in ons, maar buiten ons. Daar past de

19 David H. Kelsey, Eccentric Existence: A Theological Anthropology, Louisville, Ky 2009. Er zijn inmiddels diverse publicaties gewijd aan het boek van Kelsey, vgl. Stephen R. Milford, Eccentricity in Anthropology: David H. Kelsey's Anthropological Formula as a Way Out of the Substantive-Relational Imago Dei Debate (Princeton Theological Monograph Series 238), Eugene, OR 2019; Gene Outka, The Theological Anthropology of David Kelsey: Responses to Eccentric Existence, Grand Rapids 2016.

20 Milford, Eccentricity in Anthropology, hfdst. 3. 
metafoor 'thuiskomen' bij. Theo Boer herinnert daaraan in het recente essay dat hij schreef voor de Protestantse Kerk als hij schrijft dat voor gelovigen 'eind goed' niet in eerste instantie gaat over de goede dood maar over 'de eeuwige schuilplaats die zij vinden bij God'. Ook al tekent hij daarbij aan: 'Wat wij ons bij dat 'thuiskomen' preciezer moeten voorstellen, is moeilijk in woorden te vatten.'21

\section{Slot}

In de film 'Dialogue avec mon jardinier' (2007) trekt een succesvolle schilder uit Parijs zich terug op het platteland waar hij opgroeide en dat hij meende te zijn ontgroeid. Hij besluit de tuin van zijn ouders op te knappen. Op een advertentie reageert een oude schoolvriend, Leo Dujardin. Leo de tuinman leeft dicht bij de aarde. Later in de film blijkt dat Leo niet lang meer te leven heeft. Het gesprek met de tuinman loopt uit op een gesprek over de dood. 'Meer dan deze aarde is er niet', zo laat de tuinman zijn gesprekspartner - en de kijker - weten. Het gesprek stokt, want de hemel is leeg. Een tuinman spreekt over zijn dood, terwijl hij in zijn laatste tuin werkzaam is. Ook in een levensbeschouwing die helemaal gesloten lijkt, liggen aanzetten voor een eigen christelijke stem in de wetenschap die zich bezighoudt met de dood. Ook een gesprek met een Hovenier. Door Rembrandt geschilderd als 'de Christus met de grote hoed' (Ida Gerhardt). ${ }^{22}$

Theo Pleizier werkt als universitair docent praktische theologie aan de Protestantse Theologische Universiteit (vestiging Groningen).

21 Theo Boer, Eind goed. Een protestantse kijk op euthanasie in Nederland, Utrecht 2021, 80-81.

22 Uit De hovenier (1961). Opgenomen in Ida Gerhardt, Verzamelde gedichten 1, Amsterdam 1992, 275-337. 